Rapp. Gronlands geol. Unders. 66, 9-11 (1974)

\title{
K/Ar AGE DETERMINATIONS ON MESOZOIC LAMPROPHYRE DYKES NEAR RAVNS STOR $\varnothing$, FISKENASSET REGION, SOUTHERN WEST GREENLAND
}

\section{Kirsten Hansen and Ole Larsen}

Three K/Ar age determinations have been made by O. L. on the lamprophyre dykes cutting the Precambrian crystalline basement in the Ravns Stor $\varnothing$ area of southern West Greenland. The samples were collected by Clark Friend and Lars Skov Andersen during GGU's regional team mapping programme. The petrology of the dykes is the subject of a special study by one of us (K. H.).

\section{Sample description}

GGU 109507: N-S trending lamprophyre dyke with phenocrysts of biotite, clinopyroxene, olivine pseudomorphs (consisting of carbonate and opaque minerals) in a matrix containing clinopyroxene, biotite, carbonate and chlorite. Perovskite and opaque minerals are important accessories. The vesicles are filled with the same minerals as described for the matrix.

GGU 118295: $1 \mathrm{~m}$ wide NNE-trending lamprophyre dyke with phenocrysts of well-crystallised biotite and clinopyroxene in a matrix of pyroxene, biotite, nepheline(?), zeolites and carbonates. Apatite, perovskite and opaque minerals are important accessories. Matrix minerals occur also as vesicle fillings.

GGU 120366: 10-25 cm wide NNE-trending lamprophyre dyke with phenocrysts of clinopyroxene, euhedral olivine pseudomorphs and biotite. The phenocrysts are concentrated in the centre of the dyke. The matrix is composed of pyroxene, olivine pseudomorphs, biotite and chlorite. Accessories are opaque minerals and apatite. Vesicles are filled with carbonate and chlorite. 
Table 2. Location, analytical detail and $K / A r$ mineral ages of lamprophyre dykes from the Ravns Storo area

\begin{tabular}{lllclr}
\hline $\begin{array}{c}\text { GGU } \\
\text { sample } \\
\text { No. }\end{array}$ & Locality & Mineral & $\begin{array}{c}\mathrm{K}_{2} \mathrm{O} \\
\%\end{array}$ & $\begin{array}{c}{ }^{40} \mathrm{Ar} \text { rad. } \\
\mu \mathrm{gat} / \mathrm{g}\end{array}$ & $\begin{array}{c}\text { Age } \\
\mathrm{m} . \mathrm{y} .\end{array}$ \\
\hline 109507 & $\begin{array}{l}\mathrm{E} \text { of Ravns Storø } \\
62^{\circ} 43^{\prime} \mathrm{N} / 49^{\circ} 58^{\prime} \mathrm{W}\end{array}$ & Biotite & $9.15 \pm 0.1$ & $(1.62 \pm 0.05) 10^{-3}$ & $116 \pm 4$ \\
118295 & $\begin{array}{l}\mathrm{E} \text { of Ravns Storø } \\
62^{\circ} 39^{\prime} \mathrm{N} / 50^{\circ} 05^{\prime} \mathrm{W}\end{array}$ & Biotite & $9.23 \pm 0.1$ & $(1.71 \pm 0.07) 10^{-8}$ & $122 \pm 5$ \\
120366 & $\begin{array}{l}\mathrm{S} \text { of Ravns Storø } \\
62^{\circ} 39^{\prime} \mathrm{N} / 50^{\circ} 20^{\circ} \mathrm{W}\end{array}$ & Biotite & $7.25 \pm 0.1$ & $(1.54 \pm 0.06) 10^{-3}$ & $138 \pm 5$ \\
\hline
\end{tabular}

Decay constants: $\lambda_{e c}=5.85 \times 10^{-11} \mathrm{y}^{-1}, \lambda_{\beta}=4.72 \times 10^{-10} \mathrm{y}^{-1}{ }^{40} \mathrm{~K} / \mathrm{K}=0.0119$ atom $\%$

\section{Discussion}

The K/Ar age determinations (table 2) demonstrate that intrusion of lamprophyric magmas occurred in the southern part of the Fiskenæsset region as late as the Lower Cretaceous. The youngest dyke rock of lamprophyric affinity hitherto dated in southern West Greenland is a carbonatite on Igaussaq island just south of Frederikshåb (Walton, 1966; Larsen, 1966). A Jurassic age of $162 \pm 5$ m.y. was suggested for this dyke.

Field evidence proves beyond doubt that the lamprophyric carbonatite on Igaussaq was emplaced after the intrusion of a NW-trending dolerite dyke belonging to a coast-parallel swarm which has been mapped for more than $200 \mathrm{~km}$ along the coast. When $\mathrm{K} / \mathrm{Ar}$ whole-rock dating of one of these coast-parallel dolerites produced an age of $138 \mathrm{~m} . \mathrm{y}$. (Watt, 1969) the isotopic age of the Igaussaq carbonatite was questioned by Walton \& Arnold (1970), who suggested that the biotite used in the dating of the carbonatite may have contained excess Ar.

The present $\mathrm{K} / \mathrm{Ar}$ results show that lamprophyric magmas were injected into the crust as late as 120 m.y. ago. The two concordant results on biotites from the samples GGU 109507 and GGU 118295 give reason to believe that the K/Ar ages indicate the true age of magmatic activity.

The interpretation of the age obtained on sample GGU 120366 is less certain. The age may be explained as being anomalous and caused by the presence of excess Ar in the biotite of a younger dyke, as it could be demonstrated in the case of a kimberlite dyke rock at Nigerdlikasik (Andrews \& Emeleus, 1971); or it may be a valid age proving that this dyke was emplaced at about the same time as the coast-parallel dolerite swarm. In the latter case the dyke could be contemporaneous with the Igaussaq carbonatite supporting the idea that this dyke was formed in close relation to the dolerites as originally proposed by Walton (1966). 


\section{References}

Andrews, J. R. \& Emeleus, C. H. 1971: Preliminary account of kimberlite intrusions from the Frederikshåb district, South-West Greenland. Rapp. Grønlands geol. Unders. 31, 26 pp.

Larsen, O. 1966: K/Ar age determinations from Western Greenland. Rapp. Grønlands geol. Unders. 11, 57-67.

Walton, B. [J.] 1966: Carbonatite-lamprophyre dykes of Mesozoic age. Rapp. Grønlands geol. Unders. 11, 37-38.

Walton, B. J. \& Arnold, A. R. 1970: Plutonic nodules in lamprophyric carbonatite dykes near Frederikshåb, South-West Greenland. Bull. Grønlands geol. Unders. 91 (also Meddr Grønland 190,5) $26 \mathrm{pp}$.

Watt, W. S. 1969: The coast-parallel dike swarm of southwest Greenland in relation to the opening of the Labrador Sea. Can. J. Earth Sci. 6, 1320-1321.

Institut for Petrologi,

University of Copenhagen, $\emptyset$ stervoldgade 10, 1350 Copenhagen $K$. 